\title{
Telemonitoring and Contemporary Outpatient Management of Patients with Heart Failure: Is it Time?
}

\author{
Tamas Alexy, Gary S. Francis
}

Department of Medicine, Division of Cardiology, University of Minnesota, Minneapolis, MN 55455, USA

Correspondence:

Tamas Alexy, MD, PhD, Assistant Professor of Medicine, University of Minnesota, Division of Cardiology 420 Delaware St SE, Minneapolis, MN 55455, USA, E-mail: alexy001@umn.edu, tel.: 1 (612) 6261370

\begin{abstract}
Chronic heart failure is not going away, but continues to expand globally. This is largely driven by new cases of heart failure with preserved ejection fraction. Patients receive chronic disease management complicated by frequent hospitalizations to treat episodes of exacerbation that not only affect quality of life but is also associated with a significant financial burden to the society. With a better understanding of heart failure pathophysiology, our management strategy has shifted progressively from reactive to preventive, such as daily weight monitoring and interaction with specialized nurses. With the advent of new technology, non-invasive remote monitoring is now more available with regular, automatic data transmission to the health care center, including heart rate, blood pressure, weight and daily activity. The widespread use of implanted cardioverter defibrillators and cardiac resynchronization therapy in patients with heart failure has enabled the expansion of these devices with various indwelling sensors aimed at monitoring volume status and predicting need for hospitalization. As the success of this approach was noted to be limited, implantable hemodynamic sensors have been subsequently developed in an attempt to reduce heart failure hospitalizations and mortality. This manuscript provides a brief review and clinical utility of the available remote monitoring approaches and devices for patients with heart failure.
\end{abstract}

Keywords: heart failure, remote monitoring, hemodynamic sensors, mortality

\section{Újabb lehetőségek a telemonitorozás és a krónikus szívelégtelenség ambuláns kezelésében}

A krónikus szívelégtelenség incidenciája világszerte emelkedik elsődlegesen az újonnan diagnosztizált megtartott ejekciós frakciójú szívelégtelenségben szenvedő betegek magas számának köszönhetően. A szívelégtelen betegek krónikus ellátást és gyakori kórházi kezelést igényelnek, amely nemcsak az életminőségre van negatív hatással, de a társadalomra is jelentős anyagi terhet ró. A szívelégtelenség patofiziológiájának megismerésével párhuzamosan terápiás stratégiánk egyre inkább a reaktív felöl a preventív felé tolódott, mint például a testsúly napi követése és a szívelégtelenség ellátásában jártas nővérekkel való rendszeres kapcsolattartás. A technológia fejlődésével noninvaziv telemonitorozás is lehetővé vált, amely rendszeresen és automatikusan továbbít bizonyos paramétereket az egészségügyi centrumba, mint például szívfrekvencia, vérnyomás, testsúly és napi aktivitás. A defibrillátorok és reszinkronizációs terápia elterjedése lehetővé tette különböző szenzorok integrálását, amelyek alkalmasak lehetnek a folyadékfelesleg monitorozására és emiatti kórházi felvétel szükségességének elöre történő megjóslására. Mivel ezen módszerek sikere limitáltnak bizonyult, implantálható hemodinamikai monitorok kerültek kifejlesztésre, melyek használata a szívelégtelenség miatti halálozás és kórházi felvételek számának csökkenéséhez vezetett. Ezen közlemény a szívelégtelenségben szenvedő betegpopuláció számára rendelkezésre álló invazív és noninvazív telemonitorozási lehetőségeket, valamint az ezekkel elért eredményeket foglalja össze.

Kulcsszavak: szívelégtelenség, telemonitorozás, hemodinamikai monitorok, halálozás 


\section{Epidemiology and pathophysiology of heart failure}

Chronic heart failure (HF) is currently estimated to affect over 38 million adults worldwide (1), a prominent surge from 23 million in the 1990s (2). Despite improved preventive and therapeutic strategies, it's prevalence is projected to increase by an additional $46 \%$ by 2030 (3). In the United States (U.S.) alone, 5.7 million adults suffer from symptomatic disease currently (3) and over 500,000 new patients are diagnosed with HF annually. Based on studies performed in the U.S. and $f$ the leading diagnoses for hospitalizations and re-hospitalizations; more than $20 \%$ of patients are re admitted within 30 days of discharge and $50 \%$ by 6 months $(7,8)$. Frequent HF hospitalizations not only affect the patient's quality of life but also represent a major financial burden to the society with the total cost estimated to exceed $\$ 70$ billion in the U.S. by 2030 (9). While not all HF-related healthcare expenditures are preventable, multiple strategies and novel medical devices have been developed aiming to reduce hospital admissions and emergency room/office visits without compromising patient safety. This has required an improved understanding of HF pathophysiology and the identification of milestones whereby early intervention could reduce the risk of further decompensation.

The most common reason for acute HF exacerbation is congestion rather than a rapid, unexpected decline in cardiac output. Despite the significant structural and functional differences between HF with reduced ejection fraction (HFrEF) and HF with preserved ejection fraction (HFpEF), rising filling pressures play a pivotal role in the pathophysiology of decompensation in both syndromes (10). Using implantable pressure monitors, subtle but persistent changes can be detected up to 4 weeks prior to hospitalization (11). Within 7 days there is a prominent shift in the balance of the autonomic nervous system with sympathetic activation and reduced parasympathetic tone. These initial compensatory mechanisms lead to increased inotropy, chronotropy, vasoconstriction, activation of the renin-angiotensin system and further fluid retention. The increased intravascular hydrostatic pressure commonly leads to interstitial fluid accumulation in the lungs as well as the periphery overwhelming the lymphatic system (12). In some cases, there is simply a translocation of splanchnic fluid to the thorax without increase in weight. These changes are usually documented 1-2 weeks prior to admission and are accompanied by a decrease in thoracic impedance. Without a change in diuretic regimen, ongoing fluid retention can often, but not always, lead to a detectable increase in body weight. Clinical signs and symptoms of decompensated HF develop within approximately 7 days, ultimately prompting patients to seek medical attention.

As we gain a better understating of the pathophysio- logy of HF, non-invasive methods as well as invasive sensors have been developed aiming to recognize and block the progression of HF exacerbation at an increasingly earlier stage. Our approach has shifted from being reactive to a more preventive posture by detecting the earliest electronic signals of decompensation via implanted instrumentation. The following sections provide a brief overview of the utility, benefits and disadvantages of various interventions and devices that are currently at our disposal.

\section{Remote monitoring approaches and devices}

\section{Non-invasive remote monitoring}

Initial attempts to reduce HF hospitalizations were directed at home based, non-invasive telemonitoring. These efforts included symptomatic evaluation using structured telephone support (STS) and the use of electronic devices with digital transmission of simple physiological variables such as weight, heart rate, blood pressure and ECG to the health care team on a regular basis. The clinical, economical and behavioral benefits of non-invasive telemonitoring has been evaluated in numerous single center and large case multicenter trials with their findings summarized in multiple meta-analyses. While some studies described a benefit from these approaches in reducing HF-hospitalizations and mortality (13), other studies failed to confirm a positive impact. $2 \mathrm{~kg}$ increase in body weight over a period of 48 hours, for example, had a sensitivity of merely $9 \%$ and showed no close correlation with intracardiac filling pressures (14). This is not unexpected as fluid sometimes simply translocates from the splanchnic vascular bed to the thoracic veins. Selected trials focusing on different physiological metrics with positive and negative outcomes are listed in Table 1.

\section{Device-based monitoring}

Based on guideline recommendations for patients with HFrEF, the use of implanted cardioverter defibrillators (ICDs) and cardiac resynchronization therapy (CRT) has increased dramatically in recent years. This opened up the opportunity to build in thoracic volume sensors into these devices in an attempt to predict impending HF decompensation. Monitored parameters commonly include heart rate variability, incidence of arrhythmias, daily physical activity level, sleep patterns and thoracic impedance, each of which demonstrates an inverse relationship with pulmonary capillary wedge pressure (15). Multiple randomized trials and meta-analyses were published in the field with variable results regarding the clinical utility of these implanted devices. Selected papers with negative and positive findings are listed in Table 2.

Given the variable success with the approaches detailed above, a new device algorithm was recently devel- 
TABLE 1. Selected trials evaluating the efficacy of non-invasive telemonitoring. Green square indicates positive results red square marks studies with negative results BP: blood pressure; ECG: electrocardiogram; QOL: quality of life

\begin{tabular}{|l|l|l|}
\hline Trial & Parameters monitored & Findings \\
\hline WISH (37) & Weight & No effect on cardiac re-hospitalization, mortality \\
\hline TEHAF (38) & Symptoms, health behaviors & No effect on mortality, HF-hospitalizations \\
\hline TEMA-HF1 (39) & Weight, BP, heart rate & Reduced mortality, hospitalizations \\
\hline SPAN-CHF II (40) & BP, heart rate, weight, symptoms, adherence & Reduced 90-days hospitalizations \\
\hline DIAL (41) & Weight, symptoms, adherence, activity & Reduced HF-admissions \\
\hline TEN-HMS (42) & Weight, BP, heart rate and rhythm & No effect on admission, reduced mortality \\
\hline TIM-HF (43) & ECG, BP, weight & No effect on HF-hospitalization or mortality \\
\hline INH (44) & Signs and symptoms, nurse coordinated management & No effect on mortality and re-hospitalization \\
\hline TELE-HF (45) & Symptoms, weight & No effect on 180-days re-admissions, mortality \\
\hline BEAT-HF (46) & BP, heart rate, weight, symptoms & No effect on 180-days re-admissions \\
\hline IN TOUCH (47) & Weight, BP, blood pressure, symptoms & No effect on HF-hospitalization, mortality QOL \\
\hline Kingston-upon-Hull (48) & Weight and diastolic BP & Predicted HF-admissions (Measured over 8 days) \\
\hline
\end{tabular}

oped combining input from multiple sensors monitoring various aspects of HF pathophysiology. The hypothesis was tested in the international, multicenter, non-randomized MultiSENSE study (16). Collected data included respiratory rate, relative tidal volume, heart rate, heart sounds focusing on S3, patient activity and thoracic impedance. The HeartLogic algorithm was able to detect HF decompensation with a median lead time of 34 days, a sensitivity of $70 \%$ and an unexplained alert rate of only 1.47 per patient year. Further studies are underway to establish if widespread use of this novel algorit$\mathrm{hm}$ would reduce HF-related hospitalizations, healthcare costs, mortality and its impact on quality of life.

\section{Implantable hemodynamic monitors}

Better understanding of HF pathophysiology has also led to the development of implantable hemodynamic sensors to monitor filling pressures. The Chronicle device (Medtronic Inc, Minneapolis, MN) was designed to measure systolic and diastolic right ventricular (RV) pressure and to estimate pulmonary artery (PA) diastolic pressure using a lead secured in the RV outflow tract (17). The COMPASS-HF was a multicenter, single-blinded, randomized, parallel-controlled study designed to evaluate if hemodynamic monitoring with the Chronicle device would reduce the composite endpoint of HF-related hospitalizations and the need for IV diuretic therapy (18). Hemodynamic data were downloaded and transmitted weekly but the heart failure team could only review these for the treatment group. Compared to the controls, there was a $21 \%$ reduction in the total event rate with monitoring. Yet, the difference did not reach statistical significance. This may be explained by the lack of pre-specified pressure targets and that

TABLE 2. Selected trials evaluating the utility of device-based therapies in reducing HF outcomes. Green square indicates positive results, red square marks studies with negative results HRV: Heart Rate Variability; OptiVolTM: Proprietary algorhythm to measure electrical impedance between the device can and RV electrode (Medtronic, Inc.)

\begin{tabular}{|c|c|c|}
\hline Trial & Parameters monitored & Findings \\
\hline IN-TIME (49) & Reduced activity, arrhythmias & Reduced mortality, no effect on HF-hospitalizations \\
\hline PARTNERS-HF (50) & Arrhythmias, activity, OptiVoITM, HRV & Predicted HF-hospitalizations \\
\hline SENSE-HF (51) & OptiVolTM & Low sensitivity and predictive value for HF-hospitalization \\
\hline MORE-CARE (52) & OptiVolTM and arrhythmias & $\begin{array}{l}\text { No effect on mortality or HF-hospitalizations but reduced in-office } \\
\text { visits }\end{array}$ \\
\hline REM-HF (53) & Multiple parameters & No effect on mortality or HF-hospitalizations \\
\hline EVOLVO (54) & Multiple parameters & Reduced heart care utilization \\
\hline DOT-HF (55) & Multiple parameters & No effect on outcomes and increased HF-hospitalizations \\
\hline COMPAS (56) & HRV, arrhythmias & Reduced ambulatory clinic visits \\
\hline TRUST (57) & Arrhythmias & Reduced health care utilization \\
\hline OPTILINK (58) & Volume status & No effect on outcomes \\
\hline
\end{tabular}


medical therapy was not adjusted in response to the PA diastolic pressures. However, there was a significant $36 \%$ reduction in the relative risk of HF-associated hospitalizations and the treatment effect was more pronounced in patients with NYHA Class III symptoms. Due to the overall negative study results, the Food and Drug Administration voted against the approval of the Chronicle device.

Given the limited but encouraging success of Chronicle, a new, implantable, battery-free, wireless hemodynamic monitoring system (CardioMems ${ }^{\mathrm{TM}}$, Abbott, Minneapolis, MN) was developed. The sensor is implanted during a minimally invasive right heart catheterization with the aim to detect early, subtle changes in intracardiac and PA pressures. Sensor data were shown to correlate well with hemodynamic measurements obtained during simultaneous Swan-Ganz catheterization as well as Doppler echocardiographic assessments (19). CHAMPION, a prospective, single-blind, multicenter trial enrolled 550 patients with NYHA Class III HF symptoms with at least one hospitalization in the previous year, regardless of etiology or EF and randomly assigned them to guideline-directed optimal medical therapy with or without CardioMems ${ }^{\mathrm{TM}}$ monitoring (20). In addition to frequent clinic visits, PA pressures were monitored daily. Diuretic regimen and vasodilator therapy were adjusted based on the hemodynamic data, following a strict, pre-defined study protocol. While the trial was not powered to detect direct impact on mortality, the group managed using CardioMems ${ }^{\mathrm{TM}}$ data had a significant $28 \%$ reduction in HF hospitalizations at 6 months and $37 \%$ at 15 months. A post-hoc analysis of the patient subgroup with HFrEF (EF<40\%, 445 patients) and on maximal medical therapy revealed a significant reduction in mortality after initiating PA pressure-guided HF management (21). In addition, there was a significant drop in 30-day all cause readmission rates as well as an improvement in quality of life (22). Utilizing the CardioMems ${ }^{\mathrm{TM}}$ system was shown to be cost effective to the U.S. healthcare system in the "real-world" setting with the benefits sustained at 1 year $(23,24)$. It gained FDA approval in 2014 with the indication to reduce HF hospitalizations. These devices are costly, but so are frequent hospitalizations that they may prevent. It is too early to know if more wide-spread use of implanted pressure sensing devices will ensue.

\section{OnTrack patient self-management system}

A new, innovative iPad-based application, called OnTrack to Health, goes beyond remote monitoring. It was developed based on the observation that self-management is of critical importance for patients with chronic HF. Serving as major drivers for decompensation, the rates of dietary indiscretion and medication non adherence may reach, or even surpass, $50 \%$ in this patient population (25-28). The system is designed to promote patient engagement, active decision making and comp- liance by providing individualized daily reminders and teaching materials. At the same time, it allows for secure, real-time, two-way communication with the healthcare team. This feature is particularly important for patients living in remote areas with no easy access to medical care. Full integration with electronic medical record systems and remote monitoring equipment is ongoing. Based on initial experience, the OnTrack Health system improves patient satisfaction with health care delivery, quality of life and reduces HF-related hospitalizations.

\section{Innovative outpatient volume management strategies}

Once congestion is detected by one of the remote monitoring strategies, patient contact and rapid intervention are of critical importance. As intestinal edema progresses with rising filing pressures, the absorption and efficacy of oral medications often decline, despite dosing escalation. Developing novel outpatient approaches and strategies to deliver adequate doses of diuretics are essential in order to reduce the risk of hospital admission. While several ideas have been proposed and tested, we will review the utility of outpatient diuretic infusion clinics and subcutaneous furosemide administration.

\section{Outpatient diuretic infusion clinics}

The mainstay of HF therapy continues to be intravenous loop diuretic administration with no significant difference between the efficacy of continuous infusion and bolus dosing $(29,30)$. In response to financial incentives to reduce the expenditures associated with chronic HF management, driven primarily by expensive emergency room visits and hospitalizations, many healthcare systems have established outpatient clinics specialized in intravenous (IV) loop diuretic administration. Using standardized protocols, this approach has been shown to represent a safe and effective alternative to hospital admissions in selected, hemodynamically stable patients with mild to moderate heart failure exacerbation across a wide spectrum of EF (31). Reported side effects, including hypokalemia and worsening renal failure were transient and rare (31). While approximately one third of the population may eventually require admission and intensified HF management (32), 30-day readmission rates were shown to decrease by $10 \%$ (33) and patients spend 3 fewer days on average in the hospital per every 6 months, leading to an estimated annular saving of $\$ 12,000$ (34). Overall these findings suggest that outpatient IV diuretic administration to a selected group of HF patients is safe and improves quality of life while reducing health care expenses. More of these clinics are now appearing in the U.S. with increasingly favorable results. 


\section{Subcutaneous furosemide therapy}

Aiming to further reduce healthcare utilization and to improve quality of life, a novel, pH-neutral subcutaneous formulation of furosemide has recently been developed. In a small, phase II, proof of concept stu$\mathrm{dy}$, a total of $80 \mathrm{mg}$ furosemide was injected under the skin over 5 hours using an automated infusion pump (35). Upon direct comparison to a dose adjusted, single traditional IV furosemide injection, the new formulation provided comparable urine output with a more sustained diuretic effect. Subcutaneous furosemide was well tolerated with no evidence for worsening renal function or skin irritation. Importantly, thirty-day hospitalization rates for acute HF exacerbation was similar between the two treatment arms. Further studies with the novel furosemide formulation and the delivery pump are ongoing. It is conceivable that selected patients may eventually use this strategy at home, with guidance from the medical team, to reduce HF symptoms to the point that emergency room visit and hospital admission will not be necessary (36).

\section{Conclusions}

Management of patients with HF remains a major challenge to providers worldwide. Advances in technology enabled remote monitoring of a wide range of physiological variables by multidisciplinary health care teams. However, telemonitoring alone did not improve outcomes or reduce expenditures as described by several studies. It is the combination of monitoring, timely data interpretation and protocol-driven therapeutic interventions that prevent decompensation and may lead to a decline in HF admissions, mortality as well as health care expenses. The importance of self-management, with continuous assistance from the HF team, is increasingly recognized and improves outcomes. Novel management strategies, such as outpatient diuretic clinics and home subcutaneous furosemide infusion, may also reduce hospitalizations. Further studies and innovative management strategies are needed to reduce the burden of HF over the next decade.

\footnotetext{
References

1. Braunwald $E$. The war against heart failure: the Lancet lecture. Lancet 2015; 385(9970): 812-24. doi: 10.1016/S0140-6736(14)61889-4 2. McMurray JJ, et al. Clinical epidemiology of heart failure: public and private health burden. Eur Heart J 1998; 19(Suppl P): P9-16.

3. Mozaffarian D, et al. Heart disease and stroke statistics - 2015 update: a report from the American Heart Association. Circulation 2015; 131(4): e29-322. doi: 10.1161/CIR.0000000000000152

4. McDonagh TA, et al. Symptomatic and asymptomatic left-ventricular systolic dysfunction in an urban population. Lancet 1997; 350(9081): 829-33. doi: 10.1016/S0140-6736(97)03033-X

5. Ho KK, et al. The epidemiology of heart failure: the Framingham Study. J Am Coll Cardiol 1993; 22(4 Suppl A): 6A-13A. doi: 10.1016/0735-1097(93)90455-A
}

6. Redfield MM, et al. Burden of systolic and diastolic ventricular dysfunction in the community: appreciating the scope of the heart failure epidemic. JAMA 2003; 289(2): 194-202. doi: 10.1001/ jama.289.2.194

7. Ross JS, et al. Recent national trends in readmission rates after heart failure hospitalization. Circ Heart Fail 2010; 3(1): 97-103. doi: 10.1161/CIRCHEARTFAILURE.109.885210

8. O'Connor CM. High Heart Failure Readmission Rates: Is It the Health System's Fault? JACC Heart Fail 2017; 5(5): 393. doi: 10.1016/j.jchf.2017.03.011

9. Heidenreich PA, et al. Forecasting the impact of heart failure in the United States: a policy statement from the American Heart Association. Circ Heart Fail 2013; 6(3): 606-19. doi: 10.1161/HHF. Ob013e318291329a

10. Zile MR, et al. Transition from chronic compensated to acute decompensated heart failure: pathophysiological insights obtained from continuous monitoring of intracardiac pressures. Circulation 2008; 118(14): 1433-41. doi: 10.1161/CIRCULATIONAHA.108.783910

11. Adamson PB. Pathophysiology of the transition from chronic compensated and acute decompensated heart failure: new insights from continuous monitoring devices. Curr Heart Fail Rep 2009; 6(4): 287-92. doi: 10.1007/s11897-009-0039-z

12. Zile MR, et al. Application of implantable hemodynamic monitoring in the management of patients with diastolic heart failure: a subgroup analysis of the COMPASS-HF trial. J Card Fail 2008; 14(10): 816-23. doi: 10.1016/j.cardfail.2008.07.235

13. Inglis SC, et al. Which components of heart failure programmes are effective? A systematic review and meta-analysis of the outcomes of structured telephone support or telemonitoring as the primary component of chronic heart failure management in 8323 patients: Abridged Cochrane Review. Eur J Heart Fail 2011; 13(9): 1028-40. doi: 10.1093/eurjhf/hfr039

14. Lewin $\mathrm{J}$, et al. Clinical deterioration in established heart failure: what is the value of BNP and weight gain in aiding diagnosis? Eur J Heart Fail 2005; 7(6): 953-7. doi: 10.1016/j.ejheart.2005.06.003

15. Yu CM, et al. Intrathoracic impedance monitoring in patients with heart failure: correlation with fluid status and feasibility of early warning preceding hospitalization. Circulation 2005; 112(6): 841-8. doi: 10.1161/CIRCULATIONAHA.104.492207

16. Boehmer JP, et al. A Multisensor Algorithm Predicts Heart Failure Events in Patients With Implanted Devices: Results From the MultiSENSE Study. JACC Heart Fail 2017; 5(3): 216-225. doi: 10.1016/j. jchf.2016.12.011

17. Steinhaus D, et al. Implant experience with an implantable hemodynamic monitor for the management of symptomatic heart failure. Pacing Clin Electrophysiol 2005; 28(8): 747-53. doi: 10.1111/j.15408159.2005.00176.x

18. Bourge RC, et al. Randomized controlled trial of an implantable continuous hemodynamic monitor in patients with advanced heart failure: the COMPASS-HF study. J Am Coll Cardiol 2008; 51(11): 1073-9. doi: 10.1016/j.jacc. 2007.10.061.

19. Verdejo HE, et al. Comparison of a radiofrequency-based wireless pressure sensor to swan-ganz catheter and echocardiography for ambulatory assessment of pulmonary artery pressure in heart failure. J Am Coll Cardiol 2007; 50(25): 2375-82. doi: 10.1016/j. jacc.2007.06.061

20. Abraham WT, et al. Wireless pulmonary artery haemodynamic monitoring in chronic heart failure: a randomised controlled trial. Lancet 2011; 377(9766): 658-66. doi: 10.1016/S0140-6736(11)60101-3. 21. Givertz MM, et al. Pulmonary Artery Pressure-Guided Management of Patients With Heart Failure and Reduced Ejection Fraction. J Am Coll Cardiol 2017; 70(15): 1875-1886. doi: 10.1016/j. jacc.2017.08.010.

22. Adamson PB, et al. Pulmonary Artery Pressure-Guided Heart Failure Management Reduces 30-Day Readmissions. Circ Heart Fail 2016; 9(6). doi: 10.1161/CIRCHEARTFAILURE.115.002600 23. Martinson $M$, et al. Pulmonary artery pressure-guided heart fa- 
ilure management: US cost-effectiveness analyses using the results of the CHAMPION clinical trial. Eur J Heart Fail 2017; 19(5): 652660. doi: 10.1002/ejhf.642

24. Desai AS, et al. Ambulatory Hemodynamic Monitoring Reduces Heart Failure Hospitalizations in "Real-World" Clinical Practice. J Am Coll Cardiol 2017; 69(19): 2357-2365. doi: 10.1016/j. jacc.2017.03.009

25. Chung ML, et al. Gender differences in adherence to the sodium-restricted diet in patients with heart failure. J Card Fail 2006; 12(8): 628-34. doi: 10.1016/j.cardfail.2006.07.007

26. Evangelista L, et al. Compliance behaviors of elderly patients with advanced heart failure. J Cardiovasc Nurs 2003; 18(3): 197 206; quiz 207-8. doi: 10.1016/S1053-2498(02)00861-6

27. Monane $\mathrm{M}$, et al. Noncompliance with congestive heart failure therapy in the elderly. Arch Intern Med 1994; 154(4): 433-7. doi: 10.1001/archinte.1994.00420040107014

28. Michalsen A, Konig G, Thimme W. Preventable causative factors leading to hospital admission with decompensated heart failure. Heart 1998; 80(5): 437-41. doi: 10.1136/hrt.80.5.437

29. Peacock WF, et al. Impact of intravenous loop diuretics on outcomes of patients hospitalized with acute decompensated heart failure: insights from the ADHERE registry. Cardiology 2009; 113(1): 12-9. doi: 10.1159/000164149

30. Palazzuoli A, et al. Continuous versus bolus intermittent loop diuretic infusion in acutely decompensated heart failure: a prospective randomized trial. Crit Care 2014; 18(3): R134. doi: 10.1186/cc13952 31. Buckley LF, et al. Intravenous Diuretic Therapy for the Management of Heart Failure and Volume Overload in a Multidisciplinary Outpatient Unit. JACC Heart Fail 2016; 4(1): 1-8. doi: 10.1016/j. jchf.2015.06.017

32. Ryder M et al. Outpatient intravenous diuretic therapy; potentia for marked reduction in hospitalisations for acute decompensated heart failure. Eur J Heart Fail 2008; 10(3): 267-72. doi: 10.1016/j. ejheart.2008.01.003

33. DeVore AD, et al. Thinking Outside the Box: Treating Acute Heart Failure Outside the Hospital to Improve Care and Reduce Admissions. J Card Fail 2015; 21(8): 667-73. doi: 10.1016/j.cardfail.2015.05.009

34. Makadia S, et al. The diuresis clinic: a new paradigm for the treatment of mild decompensated heart failure. Am J Med 2015; 128(5): 527-31. doi: 10.1016/j.amjmed.2014.11.028

35. Gilotra NA, et al. Efficacy of Intravenous Furosemide Versus a Novel, pH-Neutral Furosemide Formulation Administered Subcutaneously in Outpatients With Worsening Heart Failure. JACC Heart Fail 2018; 6(1): 65-70. doi: 10.1016/j.jchf.2017.10.001

36. Francis GS, Alexy T. Furosemide Reimagined: Novel Subcutaneous Formulation for a 50-Year-Old Loop Diuretic Agent for the Treatment of Acute Decompensated Heart Failure. JACC Heart Fail 2018; 6(1): 71-72. doi: 10.1016/j.jchf.2017.10.005

37. Lynga $\mathrm{P}$, et al. Weight monitoring in patients with severe heart failure (WISH). A randomized controlled trial. Eur J Heart Fail 2012; 14(4): 438-44. doi: 10.1093/eurjhf/hfs023

38. Boyne JJ, et al. Tailored telemonitoring in patients with heart failure: results of a multicentre randomized controlled trial. Eur J Heart Fail 2012; 14(7): 791-801. doi: 10.1093/eurjhf/hfs058

39. Dendale $P$, et al. Effect of a telemonitoring-facilitated collaboration between general practitioner and heart failure clinic on mortality and rehospitalization rates in severe heart failure: the TEMA-HF 1 (TElemonitoring in the MAnagement of Heart Failure) study. Eur $\mathrm{J}$ Heart Fail 2012; 14(3): 333-40. doi: 10.1093/eurjhf/hfr144

40. Weintraub $A$, et al. A multicenter randomized controlled evaluation of automated home monitoring and telephonic disease management in patients recently hospitalized for congestive heart failure: the SPAN-CHF II trial. J Card Fail 2010; 16(4): 285-92. doi: 10.1016/j.cardfail.2009.12.012

41. Investigators G. Randomised trial of telephone intervention in chronic heart failure: DIAL trial. BMJ 2005; 331(7514): 425. doi: 10.1136/bmj.38516.398067.E0

42. Cleland JG, et al. Noninvasive home telemonitoring for patients with heart failure at high risk of recurrent admission and death: the Trans-European Network-Home-Care Management System (TENHMS) study. J Am Coll Cardiol 2005; 45(10): 1654-64. doi: 10.1016/j. jacc. 2005.01.050

43. Koehler F, et al. Impact of remote telemedical management on mortality and hospitalizations in ambulatory patients with chronic heart failure: the telemedical interventional monitoring in heart failure study. Circulation 2011; 123(17): 1873-80. doi: 10.1161/CIRCULATIONAHA.111.018473

44. Angermann CE, et al. Mode of action and effects of standardized collaborative disease management on mortality and morbidity in patients with systolic heart failure: the Interdisciplinary Network for Heart Failure (INH) study. Circ Heart Fail 2012; 5(1): 25-35. doi: 10.1161/CIRCHEARTFAILURE.111.962969

45. Chaudhry SI, et al. Telemonitoring in patients with heart failure. N Engl J Med 2010; 363(24): 2301-9. doi: 10.1056/NEJMoa1010029 46. Ong MK, et al. Effectiveness of Remote Patient Monitoring After Discharge of Hospitalized Patients With Heart Failure: The Better Effectiveness After Transition - Heart Failure (BEAT-HF) Randomized Clinical Trial. JAMA Intern Med 2016; 176(3): 310-8. doi: 10.1001/jamainternmed.2015.7712

47. Kraai I, et al. The value of telemonitoring and ICT-guided disease management in heart failure: Results from the IN TOUCH study. Int J Med Inform 2016; 85(1): 53-60. doi: 10.1016/j.ijmedinf.2015.10.001

48. Koulaouzidis $\mathrm{G}$, et al. Telemonitoring predicts in advance heart failure admissions. Int J Cardiol 2016; 216: 78-84. doi: 10.1016/j. ijcard.2016.04.149

49. Hindricks $G$, et al. Implant-based multiparameter telemonitoring of patients with heart failure (IN-TIME): a randomised controlled trial. Lancet 2014; 384(9943): 583-590. doi: 10.1016/S01406736(14)61176-4

50. Whellan DJ, et al. Combined heart failure device diagnostics identify patients at higher risk of subsequent heart failure hospitalizations: results from PARTNERS HF (Program to Access and Review Trending Information and Evaluate Correlation to Symptoms in Patients With Heart Failure) study. J Am Coll Cardiol 2010; 55(17): 1803-10. doi: 10.1016/j.jacc.2009.11.089

51. Conraads VM, et al. Sensitivity and positive predictive value of implantable intrathoracic impedance monitoring as a predictor of heart failure hospitalizations: the SENSE-HF trial. Eur Heart J 2011; 32(18): 2266-73. doi: 10.1093/eurheartj/ehr050

52. Boriani G, et al. Effects of remote monitoring on clinical outcomes and use of healthcare resources in heart failure patients with biventricular defibrillators: results of the MORE-CARE multicentre randomized controlled trial. Eur J Heart Fail 2017; 19(3): 416-425. doi: 10.1002/ejhf.626

53. Morgan JM, et al. Remote management of heart failure using implantable electronic devices. Eur Heart J 2017; 38(30): 23522360. doi: 10.1093/eurheartj/ehx227

54. Landolina $M$, et al. Remote monitoring reduces healthcare use and improves quality of care in heart failure patients with implantable defibrillators: the evolution of management strategies of heart failure patients with implantable defibrillators (EVOLVO) study. Circulation 2012; 125(24): 2985-92. doi: 10.1161/CIRCULATIONAHA.111.088971

55. van Veldhuisen DJ, et al. Intrathoracic impedance monitoring, audible patient alerts, and outcome in patients with heart failure. Circulation 2011; 124(16): 1719-26. doi: 10.1161/CIRCULATIONAHA.111.043042

56. Mabo $P$, et al. A randomized trial of long-term remote monitoring of pacemaker recipients (the COMPAS trial). Eur Heart J 2012; 33(9): 1105-11. doi: 10.1093/eurheartj/ehr419

57. Varma $\mathrm{N}$, et al. Role of Automatic Wireless Remote Monitoring Immediately Following ICD Implant: The Lumos-T Reduces Routine Office Device Follow-Up Study (TRUST) Trial. J Cardiovasc Electrophysiol 2016; 27(3): 321-6. doi: 10.1111/jce.12895

58. Bohm M, et al. Fluid status telemedicine alerts for heart failure: a randomized controlled trial. Eur Heart J 2016; 37(41): 3154-3163. doi: 10.1093/eurheartj/ehw099 